\title{
Occurrence and Distribution of Aliphatic and Polycyclic Aromatic Hydrocarbons in Surface Waters along Coastal Area of Suez Gulf
}

\author{
Nazik A. Farid, Sawsan A. Mahmoud and Omayma E. Ahmed* \\ Egyptian Petroleum Research Institute, Nasr City, Cairo, \\ Egypt.
}

\begin{abstract}
QUEZ Gulf is an area of environmental interest due to tourism, S Suez port, El-Sukhna beach, shipping activity, petroleum production, and industry activities. Water samples were collected from the coastal area of Suez Gulf, and analyzed in 2014 by Gas Chromatography, HPLC, Ultraviolet, and FT-IR spectroscopy for the spatial distribution and sources of aliphatic n-alkanes and unresolved complex mixture of fossil hydrocarbons. The ratio of UCM to $\mathrm{n}$ alkanes and CPI values in all stations indicates that the main contribution to petroleum hydrocarbon contamination is via oil and its products and 16 parent polycyclic aromatic hydrocarbons, the concentrations ranged from 13.352 to $205398.76 \mathrm{ng} / \mathrm{L}$ with a mean value of $52531.578 \mathrm{ng} / \mathrm{L}$, which exceed the maximum admissible concentrations of PAHs $200 \mathrm{ng} / \mathrm{L}$ for the water standard of European Union. The total concentrations varied from 4105 to $24229 \mathrm{ng} / \mathrm{L}$ for aliphatic hydrocarbons, the highest concentrations of total PAHs were recorded for stations near the Inlet of Suez Oil Petroleum Company (SOPC) and both of EL-Sukhna at Loloh and El-Suez beaches. Interferences of rather petrogenic and pyrolytic PAH contaminations were noticed in different locations in Suez Gulf due to petroleum products deliveries and production as well as fuel combustion emissions from boats and ships. The presences of aliphatic and aromatic hydrocarbons were confirmed by both FT-IR analysis and UV absorption spectra. The concentrations detected at each site were sufficiently high to pose a risk to marine organisms if they are exposed continuously to this concentration. Hence, continuous monitoring of the ecosystem is highly warranted.
\end{abstract}

Keywords: Hydrocarbons, PAHs, Pollution, Hydrocarbon sources and UV and FT-IR Spectroscopy.

Aliphatic hydrocarbons ( $\mathrm{AH})$ and polycyclic aromatic hydrocarbons (PAHs) are two major classes of compounds that have attracted most investigations of petroleum related hydrocarbons ${ }^{(1)}$. They enter the marine environment from various sources. Accidental oil spills, although most newsworthy, are not the only sources of those compounds in the marine environment. AH can be of both petrogenic and biogenic origin, while PAHs can be petrogenic, pyrolytic and

\footnotetext{
*Corresponding author:dr.omaymamosa@yahoo.com
} 
biogenic. Among hydrocarbons, PAHs are a wide spread class of environmental pollutants that are carcinogenic and mutagenic. Under this consideration, the United States Environmental Protection Agency (USEPA) classified 16 of them as priority pollutants ${ }^{(2)}$. Considerable amounts of petroleum products are discharged into the marine environment through runoff, industrial and sewage effluents, storm water drains, shipping activities, spillage and natural oil seeps can also be important in some areas. Significant changes in hydrocarbon composition can occur due to selective dissolution, evaporation, chemical and photo-oxidation and biodegradation. Short chain alkanes and simple aromatics are rapidly lost, but complex cyclic molecules are rarely affected and can be particularly useful in source investigations ${ }^{(3)}$. A high abundance of aliphatic hydrocarbons in water is a potential source of pollution. Sides from anthropogenic sources, hydrocarbons also have several natural sources, such as terrestrial plant waxes, marine phytoplankton and bacteria, biomass combustion and digenetic transformation of biogenic precursors ${ }^{(4)}$. The odd/even $n$-alkane concentration ratio between $\mathrm{C}_{10}$ and $\mathrm{C}_{34}$, commonly referred to as the carbon preference index (CPI), has been used to indicate their sources. Pristane (Pr) to phytane $(\mathrm{Ph})$ ratio is also of interest since high values are reliable indicator of the absence of petroleum and clearly indicate a marine biological origin ${ }^{(5)}$ although low values do not reflect the presence of petroleum ${ }^{(6)}$. As for the unresolved compounds, the UCM hump is generally considered to be a mixture of many structurally complex isomers and homologues of branched and cyclic hydrocarbons that cannot be resolved by capillary gas chromatography (GC) columns ${ }^{(7)}$. The presence of UCM is the sign of a petroleum input and/or the presence of biodegraded complex mixture of hydrocarbons. Its relative importance, expressed as the ratio of unresolved to resolve compounds (UCM/R), is commonly used as diagnostic criteria of pollutant inputs. The threshold value of UCM/R that confirms the widespread presence of petroleumrelated residue is $4^{(8)}$. Regarding hydrocarbon contamination has highlighted severe contamination (particularly by oil) in areas subject to revering discharges, navigation routes and ports ${ }^{(9)}$. Hydrocarbons in water originate from several sources which have been grouped into the following categories ${ }^{(10)}$ (1) petroleum inputs; (2) hydrocarbons (especially PAHs) released as the result of partial combustion of fuels; (3) PAHs originating from forest and grass fires (transported to the marine environment via Aeolian (atmospheric) and fluvial (reverie) processes); (4) biosynthesis of hydrocarbons by marine or terrigenous organisms; (5) early digenetic transformation of non-hydrocarbon natural products to hydrocarbons. PAHs are a group of over 100 different compounds with fused benzene rings ${ }^{(11)}$ prominent in smoke, soot, and exhausts resulting from the incomplete combustion of carbon compounds, such as petroleum ${ }^{(12)}$. The environmentally significant PAHs are those molecules that contain 2 to 7 benzene rings. PAHs are divided into two groups based on their physical, chemical, and biological characteristics ${ }^{(13)}$. The lower-molecular-weight PAHs, for example, the 2 to 3 rings of PAHs such as naphthalene's, fluorenes,

Egypt. J. Chem. 58, No. 1 (2015) 
phenanthrenes, and anthracenes, have significant acute toxicity to aquatic organisms. The high-molecular-weight (HMW) PAHs, containing 4 to 7 rings, from chrysene to coronenes, do not cause acute toxicity but are known to be carcinogenic ${ }^{(14)}$. Sixteen PAH compounds have been identified as priority pollutants due to their toxic, mutagenic, and carcinogenic characteristics ${ }^{(15)}$. Due to their low water solubility and high lipophilicity, PAHs are easily and rapidly absorbed by organisms and can be accumulated in aquatic organism or adsorbed onto the surface of suspended matter, get deposited on the sea floor and be passed onto the marine food chain. Sources of PAHs can be either petrogenic, from petroleum-related activities or pyrogenic (pyrolytic), from the incomplete combustion of diesel fuel and engine oil ${ }^{(16)}$ wood, coal, biomass of forest, grass fires, waste incinerators, and fossil fuels that are used in industrial operations and power plants ${ }^{(17)}$. Inlet and outlet water of (SOPC) is located in Zietyia area about 2-3 $\mathrm{km}$ south west of Suez city and close to the most important and famous international way (Fig. 1 ). The (SOPC) is the first national petroleum refinery in Egypt, since 1921. The company processes various kinds of crude oils and producing the following finished oil products: fuel gas, propane, butane, gasoline, jet fuel, and kerosene and gas oil. The petroleum companies take water from Suez bay and mixe it with fresh water to utilize in washing the crude oil. The amount of wastewater discharged to the Suez bay is $360000 \mathrm{~m}^{3} /$ day industrial wastes only ${ }^{(18)}$. The aim of this study is to describe the distribution of petroleum hydrocarbons (PAHs and $\mathrm{AH}$ ) and to evaluate an environmental risk assessment from PAHs contamination. In order to determine the level of pollution, the customary practice is to compare the results obtained from the analysis with the others that were sampled from similar regions. This study is aimed to provide useful data for the environmental assessment initiatives for maritime sector for such future studies.

\section{Materials and Methods}

Area of study on the Suez Gulf

The Suez Bay is the entrance of Suez Gulf and limited by latitudes $29^{\circ} 50^{\circ}$ and $29^{\circ} 56^{\circ} \mathrm{N}$ and longitudes $32^{\circ} 30^{\circ}$ and $32^{\circ} 36^{\circ} \mathrm{E}$. It is an important shipping route for oil tankers and other ships traveling through the Suez Canal, the Suez Gulf to be wholly affected by the discharged pollutants (Fig. 1\&2). Outlet and Inlet of (SOPC) is located in area about 2-3 km south west of Suez city and close to the most important and famous international way. The minimum areas and dimensions for discharge basin as a final design: number of channels, $(\mathrm{n})=$ 2 , the maximum width, $(\mathrm{B})=55 \mathrm{~m}$. Depth, $(\mathrm{d})=3.5 \mathrm{~m}$. length, $(\mathrm{L})=148 \mathrm{~m}^{(18)}$. Sampling station have selected to appreciate the direct influence of associated oil activities Suez Gulf relative to a reference background level represented by the discharge basin of (SOPC). 


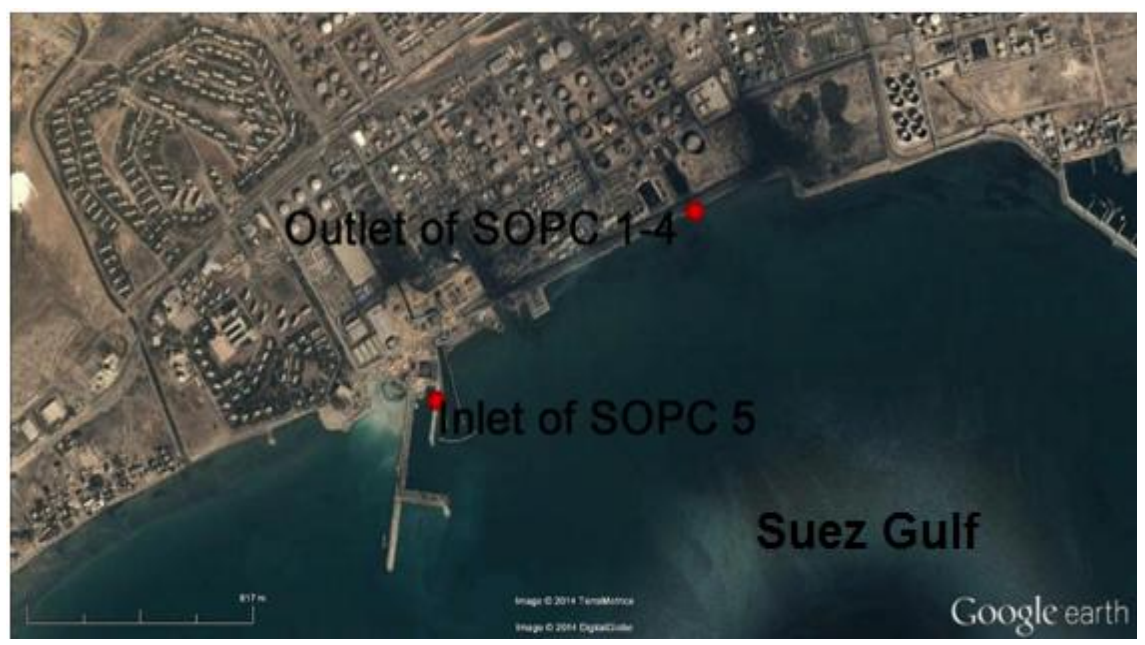

Fig. 1. Position of outlet and inlet of SOPC along the Suez Gulf .

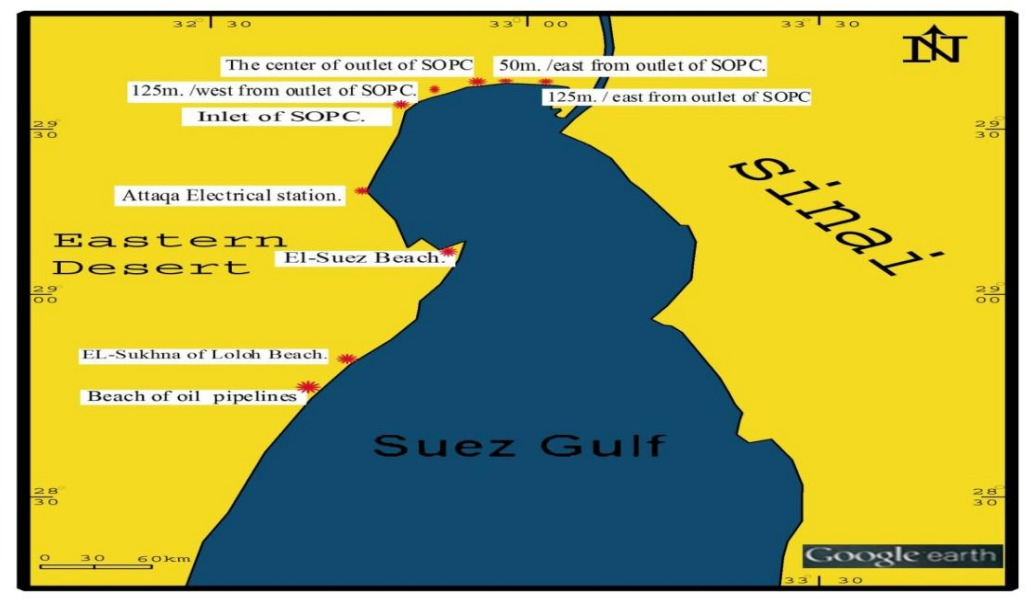

Fig. 2. Map of the area of study along the Suez Gulf .

\section{Collection of wastewater samples}

The samples are collected from the different sites in the studied area as described in Table $1 \&$ Fig. 2. The surface wastewater samples $(0-2 \mathrm{~cm})$ were taken from the drainages using plastic water sampler for wastewater analysis, the sample size was (3L) for analysis and cleaned before use; they were rinsed several time in $(0.1 \mathrm{~N}) \mathrm{HCl}$ for several days and then rinsed and protected in diluted acid to prevent degradation of oil to give proper result of analysis. During the period of study, the wastewater samples are collected from two sides of the location and mixed to make composite sample which represents one station. 
TABLE 1. Studied sites, their locations, activities and distance from the center of outlet of (SOPC) .

\begin{tabular}{|c|c|c|c|}
\hline S. No. & Locations & Activities for each site & $\begin{array}{l}\text { Distance from } \\
\text { the center of } \\
\text { drainage } \mathbf{k m} \text {. }\end{array}$ \\
\hline 1 & $\begin{array}{l}\text { The center of outlet of } \\
\text { Suez Oil Petroleum } \\
\text { Company (SOPC). }\end{array}$ & $\begin{array}{l}\text { Wastes of conversion operations of } \\
\text { crude oil to refined products at the } \\
\text { center of outlet of (SOPC). }\end{array}$ & $0.0 \mathrm{~m}$. \\
\hline 2 & $\begin{array}{l}50 \mathrm{~m} \text {. /east from outlet of } \\
\text { Suez Oil Petroleum } \\
\text { Company (SOPC). }\end{array}$ & $\begin{array}{l}\text { Wastes of conversion operations of } \\
\text { crude oil to refined products at } 50 \mathrm{~m} \text {. } \\
\text { /east outlet of (SOPC) }\end{array}$ & $50 \mathrm{~m}$./east \\
\hline 3 & $\begin{array}{l}125 \mathrm{~m} \text {. /west from outlet } \\
\text { of Suez Oil Petroleum } \\
\text { Company (SOPC). }\end{array}$ & $\begin{array}{l}\text { Wastes of conversion operations of } \\
\text { crude oil to refined products at } 125 \\
\mathrm{~m} / \text { west from outlet of (SOPC). }\end{array}$ & $125 \mathrm{~m} . /$ west \\
\hline 4 & $\begin{array}{l}125 \mathrm{~m} \text {. / east from outlet } \\
\text { of Suez Oil Petroleum } \\
\text { Company (SOPC). }\end{array}$ & $\begin{array}{l}\text { Wastes of conversion operations of } \\
\text { crude oil to refined products at } 125 \\
\text { m. / east from outlet of (SOPC). }\end{array}$ & $125 \mathrm{~m} / \mathrm{east}$ \\
\hline 5 & $\begin{array}{|lr|}\text { Inlet of } & \text { Suez Oil } \\
\text { Petroleum } & \text { Company } \\
\text { (SOPC). } & \end{array}$ & $\begin{array}{l}\text { Wastes water by sewage, Industrial } \\
\text { activities, Agricultural drainage as a } \\
\text { result of Leakages and spills in Suez } \\
\text { Gulf. }\end{array}$ & $1067 \mathrm{~m}$. \\
\hline 6 & Attaqa Electrical Station. & Electrical Station. & $3.900 \mathrm{~km}$ \\
\hline 7 & El-Suez Beach. & Recreational & $11.670 \mathrm{~km}$ \\
\hline 8 & $\begin{array}{l}\text { EL-Sukhna of Loloh } \\
\text { Beach. }\end{array}$ & Recreational & $18.730 \mathrm{~km}$ \\
\hline 9 & Beach oil pipelines & Recreational & $21.0 \mathrm{~km}$ \\
\hline
\end{tabular}

m: kilometer's

\section{Extraction of petroleum oil from seawater samples}

$100 \mathrm{ml}$ of the surface seawater sample was shaken with $100 \mathrm{ml}$ of carbon tetrachloride in a separating funnel for $15 \mathrm{~min}$. After $30 \mathrm{sec}$ agitation and $3 \mathrm{~min}$ settling period, the aqueous layer was discarded. The process was repeated until all of seawater sample has been extracted. The obtained extract was dried using anhydrous sodium sulphate $(30 \mathrm{~g})$. The extract was then transferred to a weighted beaker and finally evaporated by electrical furnace at $60{ }^{0} \mathrm{C}$ till constant weight ${ }^{(19)}$.

The oil content was calculated as: $n g$ of oil/L $=(\mathrm{A}-\mathrm{B}) \times 10^{9}$

$$
\mathrm{m} \text { L of water sample }
$$

where: A \&B are the weight of flask after and before extraction.

\section{Gas chromatography analysis}

All the oils-extracted from the studied water samples were analyzed using capillary column according to the standard test method IP318/75 ${ }^{(20)}$ for Analysis and Testing of Petroleum and Related Products. Agilent Technologies7890 A, Gas Chromatograph System, FID with HP-5, 30m Length, 0.320mn film thickness 
capillary Column. The Carrier gas was helium at flow rate of $2 \mathrm{ml} / \mathrm{min}$. The injection volume was $0.1 \mu \mathrm{I}$. Oven temperature increased from $80^{\circ} \mathrm{C}$ with a rate of $3{ }^{\circ} \mathrm{C} / \mathrm{min}$ up to $300{ }^{\circ} \mathrm{C}$. The injector temperature and detector temperature were $320{ }^{\circ} \mathrm{C}$.

High-performance liquid chromatography analysis

$\mathrm{PAH}$ identification and quantification in the extracted oil was performed using HPLC technique ${ }^{(21)}$. The apparatus used was water HPLC 600, Auto Sampler 616 Plus, Dual Absorbance Detector 2487, attached to a computerized system with Millennium 32 Software. The following were the HPLC conditions: the sample volume was $100 \mu \mathrm{l}$; the column used was Supelcosil LC-PAHs $15 \mathrm{~cm}, 4.6 \mathrm{~mm}$ ID, 4- $\mu \mathrm{m}$ particles; mobile phase was achieved using a acetonitrile/water ratio of 60:40 and was changed gradually to $100 \%$ acetonitrile within $20 \mathrm{~min}$. The flow rate was $1.2 \mathrm{ml} / \mathrm{min}$, and the detector used was a UV type, $254 \mathrm{~mm}$.

\section{Ultraviolet analysis}

Ultraviolet analysis was carried by UV/VIS/NIR Spectrophotometer (USA) V-570 JASCO, UV/VIS/NIR Spectrophotometer. The oil samples extracts were dissolved in small amounts of n-hexane, Scanning range $200-600 \mathrm{~nm}$, the absorbance (A) was measured and their ratios were calculated as A205/ A215, A228/A256, A248/A267, $\mathrm{A} 248 / \mathrm{A} 278^{(22)}$.

\section{Fourier transforms infrared spectral analysis (FT-IR)}

This technique was used for the characterization of petroleum and its degradation compounds dispersed in samples. Infrared allows us to give a picture of an oil 's health and also whether any contaminants are present such as fuel or coolant. The sample as dissolved in carbon tetrachloride (A.R.) and introduced into quartz cell for analysis. Nicolet IS-10 FT-IR, Thermo Fisher Scientific model Nicolet IS-10, CS-Q 01, AKX0901119012A0607 was used in the range $4000-500 \mathrm{~cm}^{-1(23)}$.

\section{Results and Discussion}

\section{Analysis of oil extracted from Suez Gulf waters}

Oil content

Results of gravimetric and GC-analysis show that oil content along Suez Gulf ranged from 4105 up to $24664 \mathrm{ng} / \mathrm{L}$. The lowest concentrations at beach of oil pipelines $4105 \mathrm{ng} / \mathrm{L}$ while, Attaqa Electrical Station $24664 \mathrm{ng} / \mathrm{L}$ was the most polluted station in the investigated area. The reason lies in the station uses water for cooling and discharges $1000 \mathrm{~m}^{3} /$ day of wastewater to the Suez Bay. Steady decline of oil content was observed towards beach of oil pipelines (Table $2 \&$ Fig. 3). On the other hand, outlet of (SOPC) represents oil content concentrations ranged between 5577 to $23657 \mathrm{ng} / \mathrm{L}$, the values show decline by increasing the distance far away the outlet center, as a result of water circulation and prevailing water currents inside the basin. Moreover, inlet of (SOPC) recorded $6991 \mathrm{ng} / \mathrm{L}$, this is due to the inlet and outlet of (SOPC) which located at 2-3 km south west of Suez city and close to the most important and famous international way, Suez Canal (Fig. 2). (SOPC) is the first national petroleum 
refinery in Egypt, since 1921, main activity of Suez Oil Company is the refining of oil to produce petroleum derivative products like naphtha, kerosene, gasoline, asphalt, petroleum coal and sulfur. The company has the production line for producing petroleum coal through coaling towers as well as sulfur beside; the company is located neighboring of Al -Nasr Petroleum Company in the south, the company discharges oily wastewater into the Suez Gulf, the discharge rate is $360,000 \mathrm{~m}^{3} / \mathrm{day}^{(18)}$, a decline in hydrocarbon concentration as we move from Attaqa Electrical station $24664 \mathrm{ng} / \mathrm{L}$ in to beach of oil pipelines $4105 \mathrm{ng} / \mathrm{L}$ in agreement with the prevailing water currents from the north to the south of the Gulf beside the nature of recreational activities at the beaches. Moreover, these locations received pollutants from factories outflow, industrial wastes, the shipping inputs from loading and unloading in Suez Gulf, de-ballasting of oil tankers in preparation of loading during off-shore drilling and from coastal refineries and other sources. In comparison with other studies dealing, the values of petroleum hydrocarbons in the present study (Table 2) is higher than those recorded by some authors ${ }^{(24)}$ in the Arabian Gulf (Saudi Arabia coast) which ranged from 190-3470 ng/L with an average of $890 \mathrm{ng} / \mathrm{L}^{(25)}$, represented concentration range between $20-1470 \mathrm{ng} / \mathrm{L}$ with an average $250 \mathrm{ng} / \mathrm{L}$ in the western coast of the Philippines (Thailand), Saudi Red Sea(Jeddah, Saudi Arabia) reported petroleum hydrocarbon ranged from $(<700)-2940 \mathrm{ng} / \mathrm{L}$ with an average of $80-1570 \mathrm{ng} / \mathrm{L}^{(26)}$ and from1120-6010 ng/L with an average of $3900 \mathrm{ng} / \mathrm{L}$ in the Mediterranean Sea (Damietta - Man-zalah lake) ${ }^{(27)}$ but, compared to levels recorded in the (Damietta Harbor) Mediterranean Sea is nearly lower which ranged from 14550 to- $65046 \mathrm{ng} / \mathrm{L}$ with an average of $28660 \mathrm{ng} / \mathrm{L}^{(28)}$. Moreover, other authors ${ }^{(29)}$ reported petroleum hydrocarbon ranged from 14545 to 65455 with an average of $28659 \mathrm{ng} / \mathrm{L}$ in the seawater of Damietta Harbor (Mediterranean Sea) also, concentration ranged between 18800 and $412000 \mathrm{ng} / \mathrm{L}$ with an average of $147200 \mathrm{ng} / \mathrm{L}$ recorded in the Red Sea (Saudi Arabia Coast) ${ }^{(30)}$. In addition, values between 4300 - $546000 \mathrm{ng} / \mathrm{L}$ with average concentration $111000 \mathrm{ng} / \mathrm{L}$ in the Arabian Gulf (Saudi Arabian Coast) and Suez Canal (31). Moreover, Suez Gulf displays values between 53200-376950 ng/L winter and 3888-7460 ng/L summer with average 11900 winter and $5376 \mathrm{ng} / \mathrm{L}$ summer, respectively ${ }^{(19)}$, also Suez Gulf ${ }^{(32)}$ displays values 5639-74800 and $1868-65698 \mathrm{ng} / \mathrm{L}$ with average $34460,15340 \mathrm{ng} / \mathrm{L}$ for summer and winter, respectively. These results reflect the influence of discharges from the petromin refinery (oil refinery) and also, of loading and unloading Tanker cargos at the oil terminal. Nevertheless, these data suggest that the level of petroleum hydrocarbons is higher than the level fixed by meteorology and Environmental Protection Administration of Saudi Arabia ${ }^{(33)}$. Generally, the total content of petroleum hydrocarbons recorded in the Suez Gulf is higher than that authorized by the Egyptian law of Environment No. 4 $/ 1994(50 \mu \mathrm{g} / \mathrm{L})^{(28)}$. The studied area has the potential to the maritime workshop of the refinery plant. Therefore, these areas have the potential to contaminate the adjacent waters with oil. However, total hydrocarbon concentrations in the study area were higher than those found by several authors in other coastal water, this is due to the Gulf Suez was suffering from extensive chronic 
petroleum pollution inputs from different sources, as its evident in vicinity summed pipelines company terminals, which include both floating and landbased receiving terminals. The transportation traffic results in chronic marine pollution discharges of oil ballast water and tank washings by vessels, operational spills from vessels loading or unloading at ports, accident spills from foundered vessels, and leaks from vessels in transit in the Suez bay. It is generally stated that water could be considered polluted when the hydrocarbon concentration is higher than $(2.0 \mathrm{ug} / \mathrm{L})^{(34)}$.

TABLE 2. Oil content (ng/L) extracted from sampling stations along the Suez Gulf.

\begin{tabular}{|c|l|c|}
\hline S.NO & \multicolumn{1}{|c|}{ Location } & $\begin{array}{c}\text { Oil content } \\
\text { (ng/L) }\end{array}$ \\
\hline $\mathbf{1}$ & The center of outlet of Suez Oil Petroleum Company (SOPC). & 23657 \\
\hline $\mathbf{2}$ & $50 \mathrm{~m}$. /east from outlet of Suez Oil Petroleum Company (SOPC). & 15938 \\
\hline $\mathbf{3}$ & $125 \mathrm{~m}$. /west from outlet of Suez Oil Petroleum Company (SOPC). & 6591 \\
\hline $\mathbf{4}$ & 125m. / east from outlet of Suez Oil Petroleum Company (SOPC). & 5577 \\
\hline $\mathbf{5}$ & Inlet of Suez Oil Petroleum Company (SOPC). & 6991 \\
\hline $\mathbf{6}$ & Attaqa Electrical station. & 24664 \\
\hline $\mathbf{7}$ & El-Suez Beach. & 24229 \\
\hline $\mathbf{8}$ & EL-Sukhna of Loloh Beach. & 7813 \\
\hline $\mathbf{9}$ & Beach of oil pipelines & 4105 \\
\hline
\end{tabular}

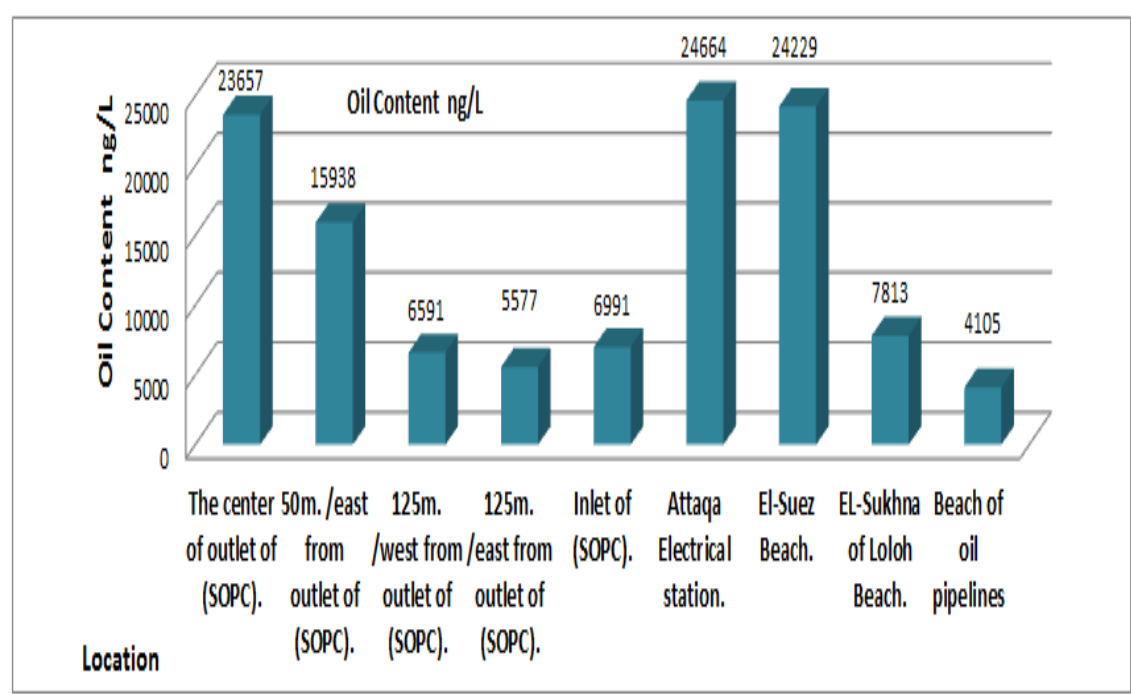

Fig. 3. Histogram representing oil content (ng/L) extracted from sampling stations along the Suez Gulf.

Egypt. J. Chem. 58, No. 1 (2015) 


\section{Gas chromatographic analysis}

\section{Gas chromatographic profiles}

Surface water samples gave chromatograms similar to those obtained for petroleum weathered profiles which are consisting of a number of peaks, representing abundant peaks over a wide $n$-alkanes range starting from $n-\mathrm{C}_{10}$ up to $n$ - $\mathrm{C}_{37}$ (Fig. 4\&5), these $n$-paraffin's are standing out an equal distances above are relatively low envelop of unresolved compounds (UCM) (Fig. 5), the isoprenoid pristane and phytane are well resolved. The primarily feature of the GC patterns for stations are the bimodal $n$-alkanes distributions S.NO.8, (Fig.5) and has been proposed as originated from mixed contributions of terrestrial plant waxes and petroleum sources from tanker ballast washing ${ }^{(35)}$. Biogenic sources for hydrocarbons are indicated by the dominance of the odd $n$ - alkanes $\left(n \mathrm{C}_{17}, n \mathrm{C}_{19}, n \mathrm{C}_{25}\right.$ and $\left.n \mathrm{C}_{29}\right)$, which are synthesized by marine algae and higher plant waxes ${ }^{(36)}$ while, S.NO.(5) (Fig. 5) shows more weathered cured oil profile with high concentration of $n$ - alkanes especially in the range of $n \mathrm{C}_{18}$ up to $n \mathrm{C}_{33}$. On the other hand, the profiles of $n$-alkanes show a homogenous distribution between odd and even number of carbons without any predominance. This fact was confirmed by the CPI (Carbon Preference Index), values close to unity could indicate an oil contamination. However, Table 3 shows values ranged between, 3.812-81.832 from CPI which indicate microbial contributions of long chain $n$-alkanes or microbial alteration of terrestrial $n$-alkenes ${ }^{(34)}$ cannot be excluded. It is noted that large envelop of unresolved complex mixtures (UCM) was the major chromatographic feature observed for this sample.

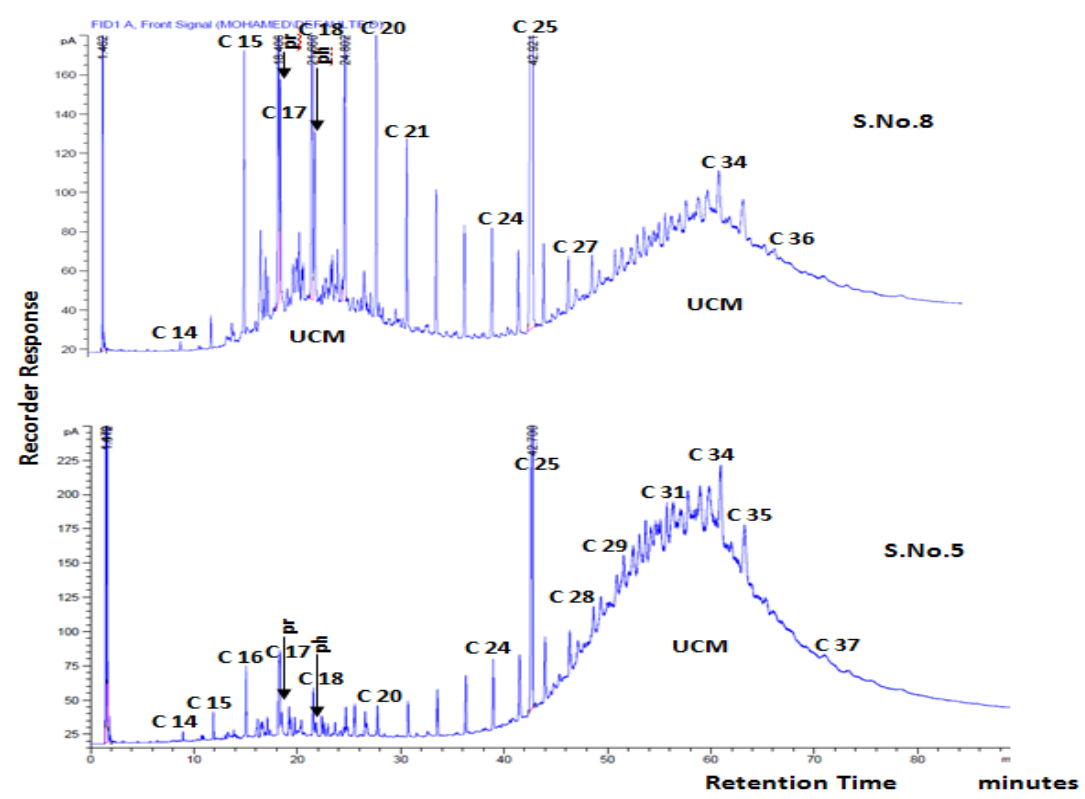

Fig. 4. Gas chromatograms of extracted oils from some selected water samples as an example of GC analysis (S. No 5 \& 8). 


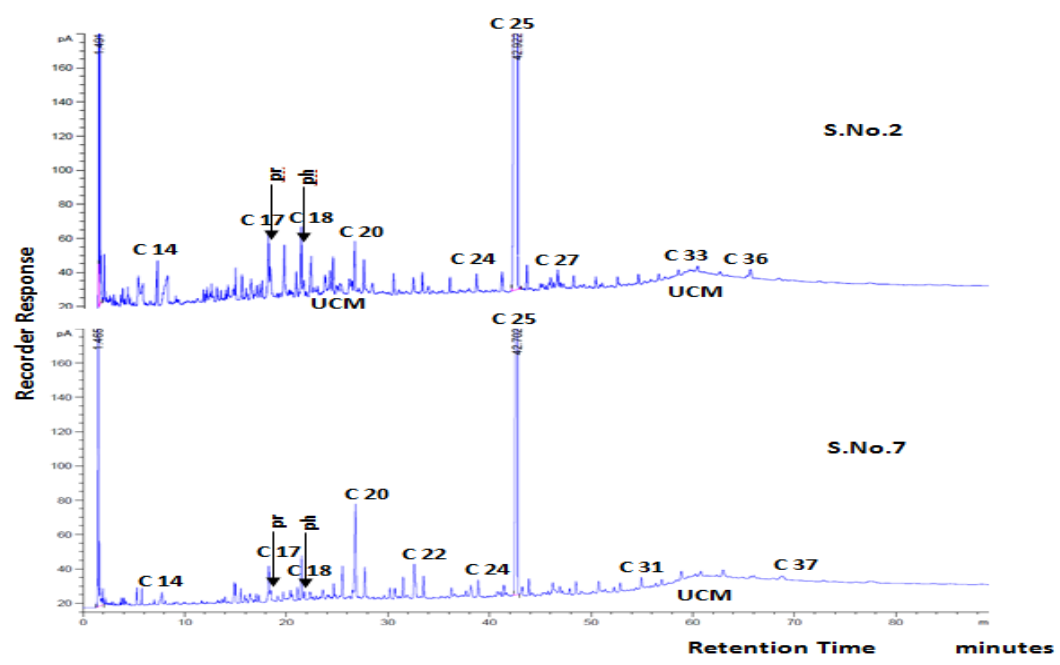

Fig. 5. Gas chromatograms of extracted oils from some selected water samples as an example of GC analysis (S. No $2 \& 7$ ).

Distribution of aliphatic hydrocarbons (AHs), biogenic versus anthropogenic sources

Th-Alkanes

The results obtained show values of resolved $n$-alkanes between 10.2360 and 94.8383 for S. NO.7, 6, respectively while, sample number $7(10.2360)$ is the lowest $n$-alkanes value of all the samples this is due, to high extensive weathering effects on the long chain $n$-alkanes on the other hand, the rest of samples exhibit good agreements between the values of S.NO. 8 (73.6421) \& S.NO.9 (73.8116) and S.NO.1 (83.1614) \& S.NO.3 (84.9056) (Table 3), which shows a general distribution of $n$-alkanes ranged between $n \mathrm{C}_{10}$ and $n \mathrm{C}_{37}$; compounds lighter than $n-\mathrm{C}_{10}$ could be lost during the evaporation of extraction solvent. This distribution appears bimodal for most samples (Fig. 5 \& 6), the first mode consisting in short chain $n$-alkanes are predominant and bimodal $n$ alkane distribution. The dominant peaks are mainly $n \mathrm{C}_{17}, n \mathrm{C}_{27}, n \mathrm{C}_{29}$ and $n_{\mathrm{C} 31}$ in most samples. This feature is related to plank - tonic ${ }^{(37)}$ and terrestrial plant wax sources ${ }^{(38)}$. Nevertheless, some samples show higher abundance of $n \mathrm{C}_{18}$ and $n \mathrm{C}_{19}$ over $n_{\mathrm{C} 17}$, which is often attributed to bacterial sources. The biogenic source is also confirmed by the presence of $n$-alkenes, identified in the range of $n \mathrm{C} 16$ to $n \mathrm{C}_{21}, n C_{15}$ to $n \mathrm{C}_{19} \mathrm{n}$-alkenes are related to algal sources ${ }^{(39)}$ and are phytoplankton biomarkers ${ }^{(40)}$. On the other hand, the profiles of $n$-alkanes show a homogenous distribution between odd and even number of carbons without any predominance. This fact was confirmed by the CPI (Carbon Preference Index), values close to unity could indicate an oil contamination. However, microbial contributions of long chain $n$-alkanes or microbial alteration of terrestrial $n$ - alkanes cannot be excluded.

Egypt. J. Chem. 58, No. 1 (2015) 


\section{Tn-alkanes / Iso-alkanes}

Normal alkanes are usually degraded more rapidly than the isoprenoid alkanes ${ }^{(19)}$. So this ratio is used as an index for the degree of weathering (mainly biodegradation). This ratio decreases with increasing weathering (41), results obtained for samples (Table 3 ) show the following sequences respectively for increasing biodegradation, weathering $6<3<1<5<9<8<2<4<7$. The relatively higher differences between the sequences and that of the other parameters are due to the differences in the added biogenic hydrocarbons specially that of $n \mathrm{C}_{25}$.

\section{$U C M$}

In addition to the chromatographically resolved compounds, an unresolved complex mixture (UCM) of hydrocarbons is present in most samples (Fig. 5\& 6) in the range $n \mathrm{C}_{25}$ to $n \mathrm{C}_{35}$. However, in some samples, it appears as a bimodal hump in the range $n \mathrm{C}_{17}$ to $n \mathrm{C}_{25}$ and $n \mathrm{C}_{29}$ to $n \mathrm{C}_{35}$. The $\mathrm{UCM}$ is generally considered as a mixture of many structurally complex isomers and homologues' of branched and cyclic hydrocarbons that cannot be resolved by capillary columns ${ }^{(42)}$. Further, the presence of the UCM in the aliphatic fraction is considered as the most important indicator of petrogenic pollution by weathered or degraded petroleum residues ${ }^{(43)}$ when, the maximum height occurs mainly in the higher molecular weight. Yet, it has also been linked to bacterial degradation of natural organic inputs (algal detritus). The (UCM \%) 8.434 to $88.340 \%$ varies from ng/L moreover, resolved components (R \%) exhibit values between 11.66 to $91.566 \%$ (Table 3).

The ratio of the unresolved to resolved components (U/R) has been calculated for most samples. Usually $U / R>4$ is used as a criterion for the presence of important petroleum residues ${ }^{(8)}$. In this study, four samples show U/R > 4, S.NO.8 (6.1241), S.NO.5 (6.286), S.NO.2 (7.570) and S.NO.4 (4.692), these results can be explained by the nearness to continental activities from different sources, beside refinery companies which discharge their wastewaters to the Gulf Suez, the rest of samples revealed values between 0.0921 to 2.130 indicating biogenic contamination.

Isoprenoids, Pristane ( $\mathrm{Pr}$ ) and phytane $(\mathrm{Ph})$ are the most common isoprenoids detected in surface seawaters ${ }^{(44)}$. They are present in most of our samples. The ratio of pristine $v s$. phytane $(\mathrm{Pr} / \mathrm{Ph})$ has been used as an indicator of the redox conditions in contaminated wastewaters; the $\mathrm{Pr} / \mathrm{Ph}$ ratio is higher than one confirmed biogenic contamination $^{(45)}$ as recorded in S.NO.3 (1.8837). From Table 3 the ratio $\mathrm{Pr} / \mathrm{Ph}$ in all our samples is lower than1.Oranging from 0.6099 to 1.1765 confirming a petrogenic contamination ${ }^{(46)}$. On the other hand, the ratios $n \mathrm{C}_{17} / \mathrm{Pr}$ and $n \mathrm{C}_{18} / \mathrm{Ph}$, usually used as indicators of hydrocarbon degradation ${ }^{(47)}$ indicate, for most samples, degraded material of biogenic inputs, however, most samples show high values of $n \mathrm{C}_{17} / \operatorname{Pr}$ ratio which could be related to the relatively high contents of $n \mathrm{C}_{17}$ in several stations.

Carbon preference index (CPI)

Biogenic hydrocarbons are characterized by a distribution pattern of $n$-alkanes showing odd carbon numbered alkanes being much more abundant than even carbon 
numbered alkanes mainly in the range of $\left(n \mathrm{C}_{21}\right.$ to $\left.n \mathrm{C}_{33}\right)$ resulting in high $\mathrm{CPI}$ values, which is defined as the sum of the odd carbon numbered alkanes to the sum of even carbon numbered alkanes. On the other hand, petroleum oils are characterized by CPI values around 1.0. Thus CPI data from surface seawater samples ranged from 1.6445 to 81.832, (Table 3) which reveals a biogenic contamination origin. But this assumption cannot be accepted by discussing the profiles of the chromatograms obtained which are shown to be typically petrogenic origin ${ }^{(38)}$. Thus the CPI values were calculated again without taking in consideration the value of $\left(n \mathrm{C}_{25}\right)$ peak areas. The results show that the $\mathrm{CPI}^{*}$ corrected values are ranging from 0.6390 to 1.8771.This indicate that petrogenic origin is mainly predominating, while little biogenic contaminations can be detected especially that of $\left(n \mathrm{C}_{25}\right)$.

$n C_{14}-n C_{18} /$ five isoprenoid in between ratio

The ratio of $n$-alkanes /isoprenoids is defined as the ratio of the sum of $\mathrm{nC}_{14^{-}}$ $\mathrm{nC}_{18}$ over the sum of farnesane, trimethylC $\mathrm{C}_{13}$, norpristane, pristane and phytane ${ }^{(20)}$, this ratio is often used to indicate the degree of biodegradation, weathering, because $n$ - alkanes are readily degraded than the branched species, Table 3 shows that the studied water samples exhibit values varied between $0.2733-0.8650$, due to intensive weathering, on the contrary S.NO. (3, 9, 4 \& 8) display high values $(2.4022,2.5240,3.570$ and 4.4402$)$ respectively, indicating that they were freshly spilled in these sites and according less weathered oils.

$n C_{10}-n C_{25} / n C_{17} n C_{25}$ ratio

This ratio is used to indicate the addition of Algal biosynthesized hydrocarbons and /or degree of weathering ${ }^{(23)}$. Data obtained from studied samples show that most of samples exhibited close values between 1.0106 and 1.0018 , this means no significant variations in degree of weathering. On the other hand, the rest of samples had slightly higher values ranged from 1.0303 up to 1.1679 being exposed to less weathering effects, (Table 3).

Weathering ratio

$\mathrm{WR}=\left(\mathrm{nC}_{23}-\mathrm{nC}_{34}\right) /\left(\mathrm{nC}_{11}-\mathrm{nC}_{22}\right)^{(39)}$, the weathering ratio which varies from 1.8094 to 111.182 indicating high weathering (Table 3 ). This can be confirmed by observing the low concentrations of low molecular weight, $n$-hydrocarbons (Fig. 5 \& 6).

Low molecular weight (LMW) / High molecular weight (HMW)

The ratios of low molecular weight (LMW, sum of $n \mathrm{C}_{10}$ to $n \mathrm{C}_{20}$ ) to high molecular weight (HMW, sum of $n \mathrm{C}_{21}$ to $\left.n \mathrm{C}_{34}\right)^{(48)}$. It appears that for all stations, the concentrations of $n \mathrm{C}_{10}$ to $n \mathrm{C}_{20}$ hydrocarbons were less concentrated than the longer chain (>20) $n$-alkanes. LMW/HMW $n$-alkanes are indicated in Table 3 . It has been reported that LMW/HMW ratios that are less than unity 1.0 usually represent $n$ alkanes produced by higher plants, marine animals and bacteria, while LMW/HMW ratios close or greater than unity 1.0 suggest $n$-alkanes that are mainly from petroleum and plankton sources ${ }^{(49)}$. As summarized in Table 3, the LMW/HMW ratios which are all lower than unity for all samples, ranged between $0.0063-0.5460$ indicating the presence of $n$-alkanes in the surface water which is mainly from biogenic-originated contaminations.

Egypt. J. Chem. 58, No. 1 (2015) 


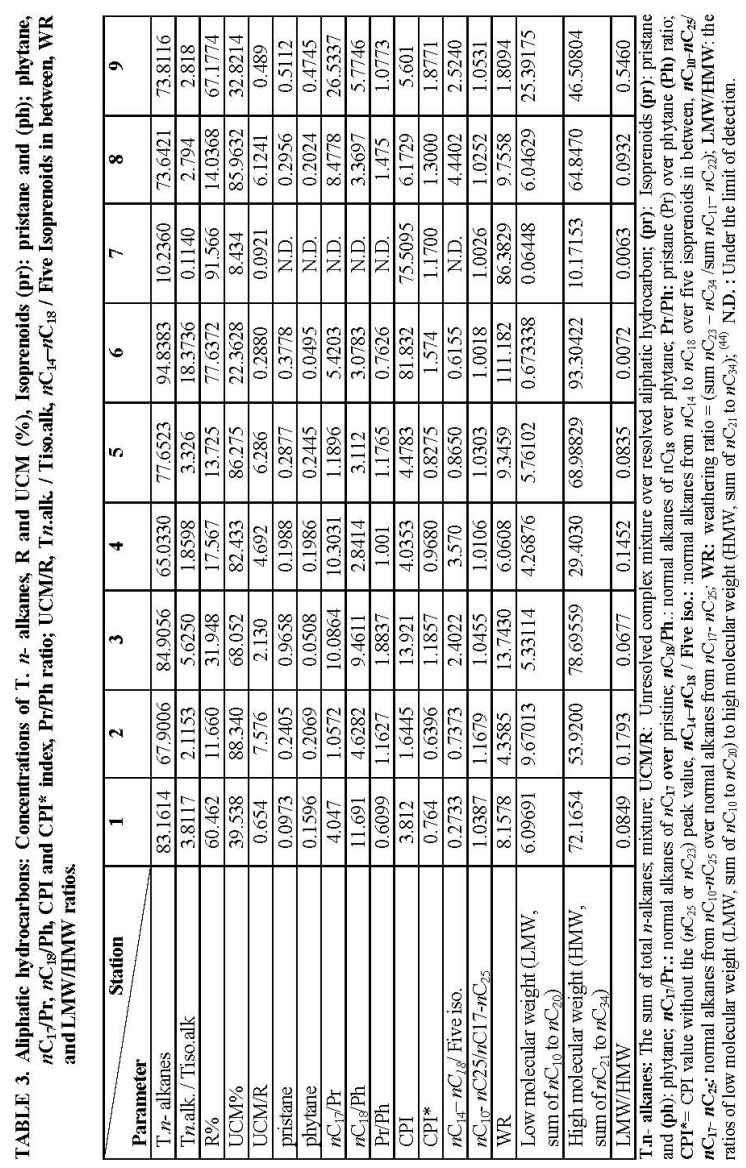

Egypt. J. Chem. 58, No. 1 (2015) 
PAH concentrations in surface waters

The mean total concentrations of 16 PAHs

poly-aromatic hydrocarbons in surface waters ranged from 13.352 at $(125 \mathrm{~m}$.), from the drainage center at the east of (SOPC) and $205398.76 \mathrm{ng} / \mathrm{at}$ Inlet of (SOPC) (Fig. 6), the highest concentration at Inlet of (SOPC) 205398.76 $\mathrm{ng} / \mathrm{L}$ due to the Suez Gulf is used in many areas as a recipient for wastewaters from different sources, which highly polluted it with wastes from drains directly into it. The amount of PAHs detected there is obviously related to urban runoffs, sewage discharges, and intense shipping and oil refinery activities, ship breaking and oil seepage from industrial activities near the study area, lead to high concentrations of total PAHs. Additionally, boats and ships transports in these regions were discharging black smokes throughout their movement; hence there are many nonpoint sources in the bay, contributing to the wide variations of PAH concentrations detected. Moreover, the level of (PAHs) are found to vary widely depending on sites with the west coast of discharge basin recorded higher value than the east coast ones, this is consistent with the direction of the water currents and winds from the west to the east side's within the basin. Similarly, high concentration $184007.91 \mathrm{ng} / \mathrm{L}$ was also found at El-Suez beach, which is close to sewage outlet from Attaqa Electrical station have a surface area of about $4 \mathrm{~km}$ along the Suez Gulf. Many of the samples from drainage of (SOPC) and beach of oil pipelines represented concentrations in excess of $\mathrm{ng} / \mathrm{L}$, suggesting that the water in the area was heavily contaminated by PAHs. Such a wide range of PAHs at different concentrations indicates that there are potentially many different sources of PAHs in the area, possibly including combustion followed by oil residues, sewage outfalls, and industrial wastewater. From the distribution of PAHs in water alone, it is difficult to differentiate these different sources of input, nevertheless, collected from different locations along the Suez Gulf. The data can act as an indication of the potential impacts of such high levels of PAHs on the local ecosystems. The total PAH concentrations found in water along the Suez Gulf, are several orders of magnitude higher than those detected in various other studies around the world. Similarly, comparable high levels of PAHs were also found in seawater samples of Daya Bay, China 4228-29320 ng/L ${ }^{(50)}$ and northern Spanish 190-28800ng/L ${ }^{(51)}$. In addition, to values recoded between $8660-46740 \mathrm{ng} / \mathrm{L}$ in Mumbai Harbor Line, India ${ }^{(52)}$. Although PAHs do not show extremely high acute toxicity to aquatic organisms, the lower molecular mass compounds tend to exhibit higher lethal toxicity than the larger PAHs ${ }^{(53)}$. And above all this lethal concentration (LC50) down to less than $10000 \mathrm{ng} / \mathrm{L}$ has been reported for various organisms ${ }^{(54)}$ beside, represent value ranged between 52811-559096 ng/L in Alexandria coast, Egypt ${ }^{(55)}$ Suez, Gulf recorded values 3115-252786, 15392-66718 ng/L ${ }^{(56)}$ for winter and summer, respectively, also Suez Gulf revealed values between 164039139 and731.7-219373 ng/L ${ }^{(57)}$ for summer and winter seasons (Table 4). The PAH concentrations detected in water samples of Inlet (SOPC)and El-Suez beach clearly (Fig. 7) show that these results are higher than the safe limits of 
the EPA National Recommended Water Quality Criteria for the protection of aquatic life and human health $(200 \mathrm{ng} / \mathrm{L}){ }^{(58)}$. The total PAH levels at the Inlet of (SOPC) and El-Suez beach and EL-Sukhna of Loloh beach are significantly higher than the maximum admissible concentrations of the European Union of $200 \mathrm{ng} / \mathrm{L}^{(58)}$, also, these are either within or higher than that of the Annual Average Environmental Quality Standards (AA-EQS) of European Water Framework Directive (WFD)for individual PAHs, which states that the safe range for PAHs is from $2.0 \times 10-2$ to $2.4 \mu \mathrm{g} / \mathrm{L}^{(59)}$. In addition, water with total PAH concentrations above $10000 \mathrm{ngL}-1$ can be ranked as heavily contaminated by PAH pollutants ${ }^{(60)}$.

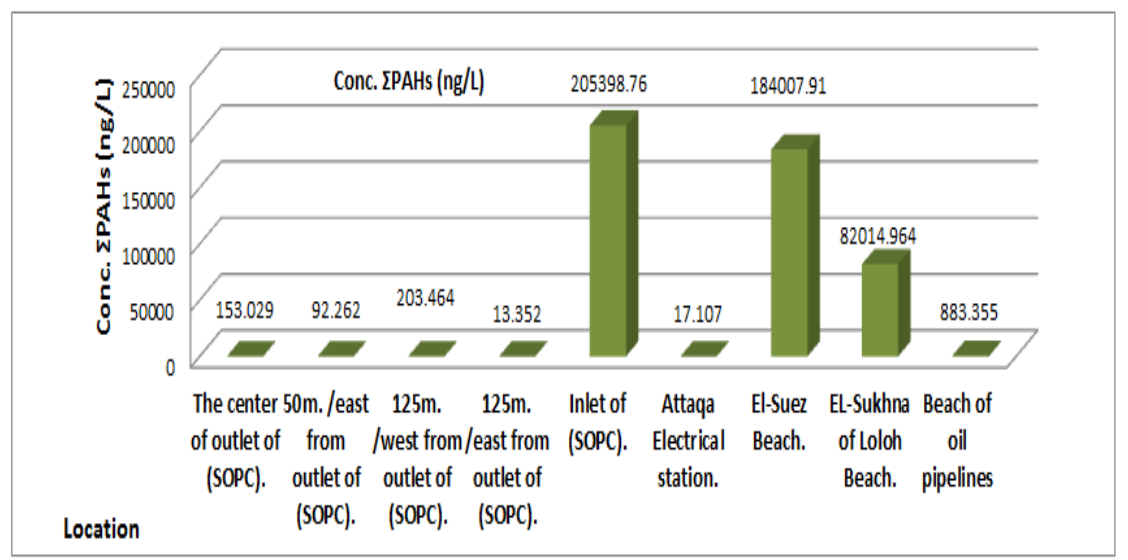

Fig. 6. Histogram representing average concentration of $\Sigma$ PAHs (ng/L) in the oil extracted from sampling stations along the Suez Gulf.

\section{PAH composition}

The composition pattern of PAHs by ring size for the samples collected from the Suez Gulf is shown in Table 4 and Fig.7. The high-molecular-weight PAHs of four rings (FIu, Pyr, BaA, and $\mathrm{Chr}$ ), five rings $(\mathrm{BbF}, \mathrm{BkF}, \mathrm{BaP}$, and DahA) and six rings (IP, BP) were dominated by HMW-PAHs (4-6 rings), representing the range of $0.085-100 \%$, which are likely derived from anthropogenic activities ${ }^{(61)}$ such as incomplete fuel combustion of the boats, ships, and vehicle engines. However, the lower-molecular-weight PAHs of two rings (Nap) and three rings (Ac, Ace, F, Phe, and Ant) made up zero and 99.917\% of the total PAH concentrations, respectively. LMW-PAHs (2-3 rings) were the lowest abundant components in water samples. The results suggest a relatively recent local PAHs source which entered into the seawater due to the inefficient two-stroke outboard engines of most boats in Suez Gulf that usually involve the discharge to the water of about $20 \%$ of fuel without burning ${ }^{(62)}$. The water sample represented an approximately equal content of HMW-PAHs 0.085-100 \%, and LMW-PAHs zero - 99.917\% (Fig.7), which probably reflects both anthropogenic activities and recent local PAH sources due to the tourism boats and ships activities dissolved onto the surface waters. 


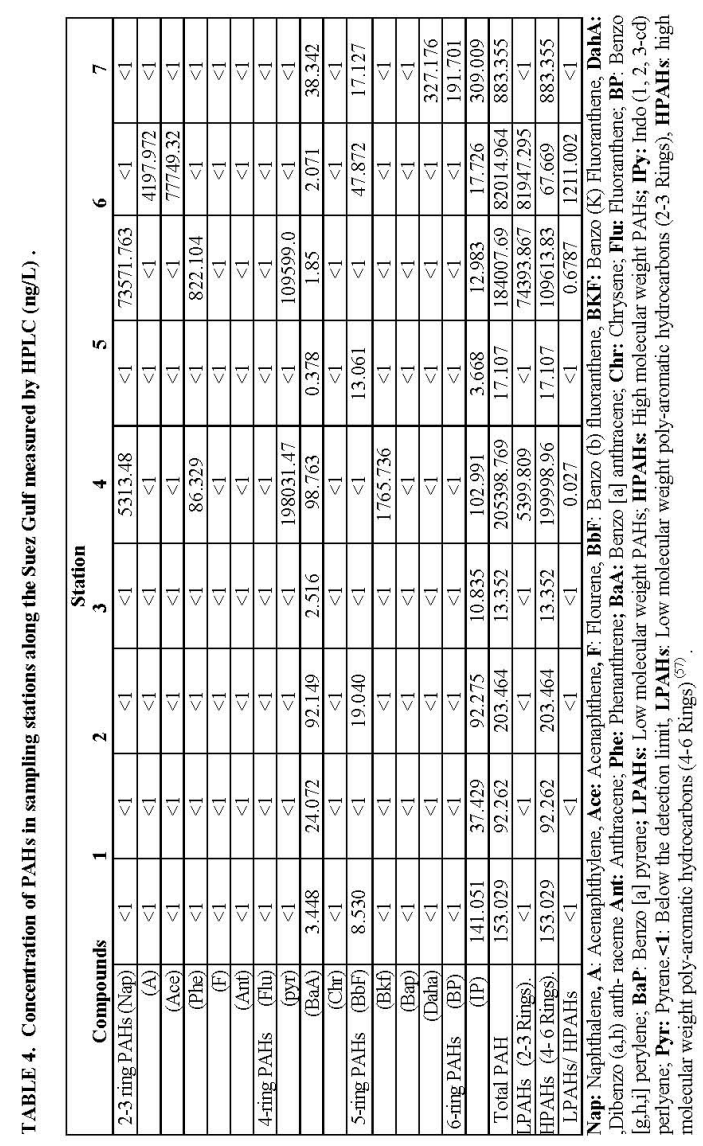

Egypt. J. Chem. 58, No. 1 (2015) 


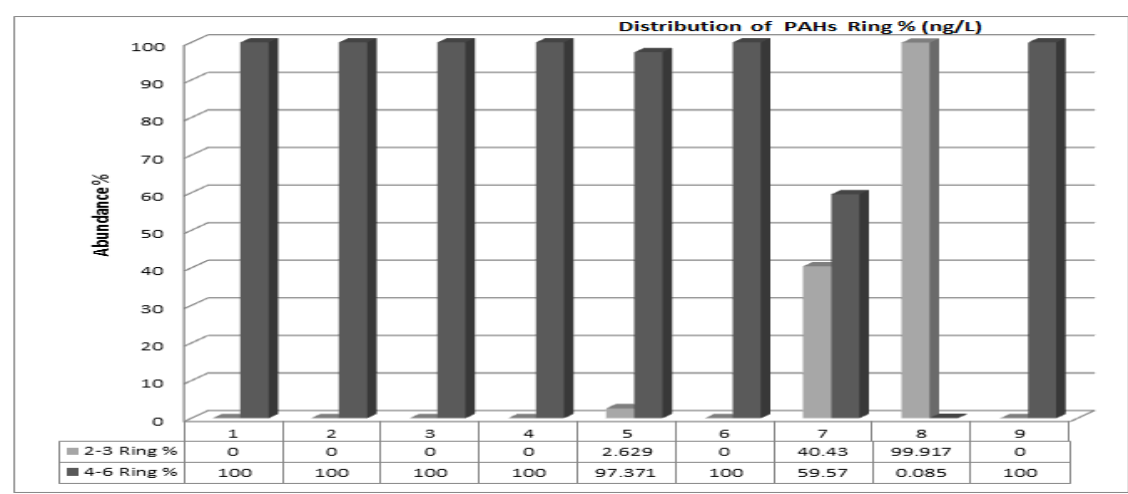

Fig. 7. Histogram represented the distribution of PAHs \% along the Suez Gulf according to number of aromatic rings .

\section{Identification of PAH sources}

The difficulty in identifying the PAH sources relies on many factors, the possible coexistence of many origins of pollutants and the transformation process that PAHs can undergo before or after discharged to the surface waters $^{(63)}$. The level of Benzo [ghi] perylene (BP), 883.355ng/L recorded in beach of oil pipeline S.NO.9 (Table 5) and this compound has the fingerprint of a combustion engine and is more abundant in soot ${ }^{(64)}$. Moreover, Benzo [a] pyrene $(\mathrm{BaA})$, the most carcinogenic pollutant of all PAHs ${ }^{(58)}$ reveals values ranged between 0.378 and $98.763 \mathrm{ng} / \mathrm{L}$, (Table 5). A study supported that the phenomenon of BP emission coming from engines ${ }^{(61)}$. The study mentioned that the highest abundance of BP was recorded at S.NO.9 which found vicinity to EL-Sukhna of Loloh beach where, the tourism boats and ships activities along the Suez Gulf and that incomplete fuel combustion was its source. Therefore, the amount of BP measured in site 9 was most probably related to the incomplete fuel combustion of the boats and vehicle engines that were extensively used in the Gulf. The petrogenic source is a result of the direct input from petroleum and its products, while the pyrogenic sources are a result of incomplete combustion of fossil fuels ${ }^{(65)}$. The calculated ratios for the LMW/HMW for all stations were between 0.027 and 1211.002, (Table 6) which suggests that the sources of PAHs from both pyrogenic (ratio of <1) and petrogenic (ratio of $>1$ ) ${ }^{(64)}$. Some stations derived their PAHs from both sources. However, this generally suggests that PAHs can be largely attributed to combustion with a contribution from petrogenic sources. Distinguishing the sources of PAHs by the diagnostic ratios chosen could reveal the inputs of the pyrogenic material. Moreover, the diminution of the level of low-molecularweight PAHs which ranged between $<1$ - 81947.295 ng/L in some stations compared to high-molecular weight PAHs ranged between 13.352 -199998.96 ng/L (Fig. 8) can also reflect a lesser amount contributed by petrogenic sources due to the direct discharge of unburned fuel of the two-stroke engine boats. 
TABLE 5. Calculated UV absorption ratios for the oil extracted from surface water along the Suez Gulf.

\begin{tabular}{|c|c|c|c|c|c|}
\hline S.NO & Location & $\begin{array}{l}\text { A205/ } \\
\text { A215 }\end{array}$ & $\begin{array}{l}\text { A228/ } \\
\text { A256 }\end{array}$ & $\begin{array}{l}\text { A248/ } \\
\text { A267 }\end{array}$ & $\begin{array}{l}\text { A248/ } \\
\text { A278 }\end{array}$ \\
\hline 1 & The center of outlet of (SOPC). & 1.068 & 0.868 & 0.866 & 0.748 \\
\hline 2 & $50 \mathrm{~m}$. /east from outlet of (SOPC). & 1.136 & 0.808 & 0.822 & 0.781 \\
\hline 3 & $125 \mathrm{~m}$. /west from outlet of (SOPC). & 1.096 & 0.905 & 0.883 & 0.806 \\
\hline 4 & $125 \mathrm{~m}$. / east from outlet of (SOPC). & 1.017 & 0.905 & 0.883 & 0.783 \\
\hline 5 & $\begin{array}{l}\text { Inlet of Suez Oil Petroleum } \\
\text { Company }\end{array}$ & 1.052 & 0.862 & 0.916 & 0.862 \\
\hline 6 & Attaqa Electrical Station. & 0.950 & 0.834 & 0.899 & 0.874 \\
\hline 7 & El-Suez Beach. & 1.039 & 0.866 & 0.845 & 0.751 \\
\hline 8 & EL-Sukhna of Loloh Beach. & 1.081 & 0.852 & 0.869 & 0.791 \\
\hline 9 & Beach of oil pipelines & 1.027 & 0.889 & 0.858 & 0.807 \\
\hline
\end{tabular}

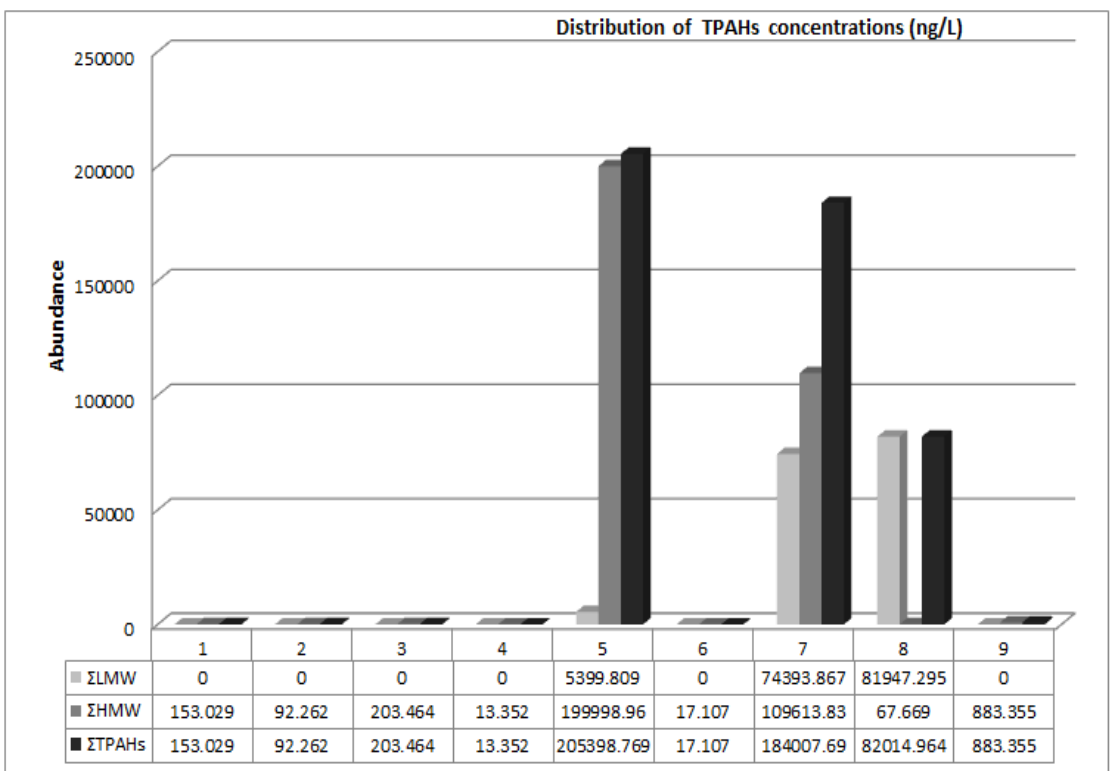

Fig. 8. The total of $\Sigma$ LMW, $\Sigma$ HMW, and $\Sigma$ PAHs concentrations (ng/L) in sampling stations along the Suez Gulf.

UV spectral analysis

The UV spectra for oils extracted from the seawaters are pointed to in Table 5. All the studied samples have the same basic features (Fig.9), depict distinguished bands around 205, 215, 228, 248, 256, 274 and 278nm. This denotes that different aromatic classes are present in the extracted oils ${ }^{(66)}$. Four absorption bands ratios were calculated from the UV spectra recorded in Table 5. The first ratio 205/215 has the same nearly value for all locations excluding location 2

Egypt. J. Chem. 58, No. 1 (2015) 
(1.136) which has a slight higher value. This indicates low concentrations for mono-aromatic hydrocarbons ${ }^{(23)}$. The second ratio 228/256 ranged between 0.808-0.905 ng/L, with a good an agreement between samples 1(0.868), 5 $(0.862)$ and $7(0.866)$ also, both of S.NO. $3 \& 4$ have the same value $(0.905)$ exhibit the typical concentrations value. This ratio has been taken as a good parameter for petroleum input, which reveals different sources of oils polluted these areas and is constant for oil and independent on oil concentration. The third ratio 248/267 has values varying between 0.883 and $0.915 \mathrm{ng} / \mathrm{L}$ with averaging concentration $0.871 \mathrm{ng} / \mathrm{L}$ this ratio is significant for di-aromatic hydrocarbons ${ }^{(20)}$. The last ratio $248 / 278$ ranging from 0.751 to $0.874 \mathrm{ng} / \mathrm{Land}$ good matching between samples, this ratio is significant for poly-aromatics hydrocarbons indicating the presence of different types of poly-aromatics, these aromatics are described as the most carcinogenic compounds which have great toxic and harmful effects threaten human life ${ }^{(67)}$.

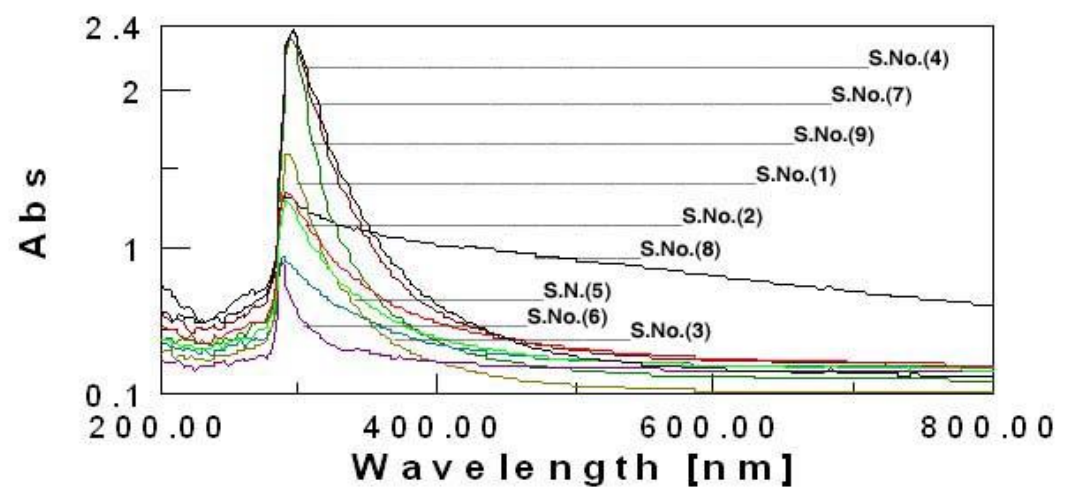

Fig. 9. UV absorption spectra for oils extracted from water samples along the Suez Gulf .

\section{FT-IR spectral analysis}

FT-IR spectra for the oils extracted from the Gulf water samples are shown in Fig.10 and presented in Table 6. The characteristic bands for aliphatic hydrocarbons appear as strong bands at $3600 \mathrm{~cm}^{-1}$ due to $\mathrm{OH}$ stretching, $\mathrm{NH}$ stretching beside, $\mathrm{CH}$ stretching in aromatic ring at $3100 \mathrm{~cm}^{-1(20)}$.

A strong band at 2924 and $2853 \mathrm{~cm}^{-1}$ due to a stretching vibration of methylene groups $\left(\mathrm{Vas} \mathrm{CH}_{3}\right)$ and $\left(\mathrm{Vs} \mathrm{CH}_{2}\right)$ stretching vibration, respectively ${ }^{(23)}$.

Strong bands at $1462 \mathrm{~cm}^{-1}$ due to $\left(\delta \mathrm{as} \mathrm{CH}_{3}\right)$ bending stretching of aliphatic hydrocarbons, vibration of $\mathrm{CH}_{3}$ group and medium band at $1377 \mathrm{~cm}^{-1}$ due to $\left(\mathrm{S}_{\mathrm{CH}} \mathrm{H}_{3}\right)$ bending of $\mathrm{CH}_{3}$ group ${ }^{(20)}$.

Medium band at $740 \mathrm{~cm}^{-1}$ due to out of plane bending of $=\mathrm{C}-\mathrm{H}$ group in mono and poly-nuclear aromatics. Indeed, weak band of Cis-disubstituted alkenes (vinyl) appears at $670 \mathrm{~cm}^{-1}$. Finally, an intense band in the region at $1724 \mathrm{~cm}^{-1}$ due to carboxylic ester ${ }^{(68)}$. 
TABLE 6. Infra-red signals and assignments of the oil extracted from the surface waters .

\begin{tabular}{|c|l|}
\hline $\begin{array}{c}\text { Wave number } \\
\mathrm{cm}^{-1}\end{array}$ & Assignments of chemical groups \\
\hline 3600 & OH stretching, $\mathrm{NH}$ stretching \\
\hline 3100 & $\mathrm{CH}$ stretching \\
\hline 2924 & A stretching vibration of methylene groups $\left(\mathrm{Vas}^{\mathrm{CH}_{3}}\right)$ \\
\hline 2853 & A stretching vibration of methylene groups $\left(\mathrm{Vs} \mathrm{CH}_{2}\right)$ \\
\hline 1462 & $\delta$ as $\mathrm{CH}_{3}$ bending stretching of vibration of $\mathrm{CH}_{3}$ group \\
\hline 1377 & $\delta$ s CH3 bending stretching of vibration of $\mathrm{CH}_{3}$ group \\
\hline 740 & $\begin{array}{l}\text { out of plane bending of }=\mathrm{C}-\mathrm{H} \text { group in } \mathrm{mono}_{\text {and }} \text { aromatics } \\
\text { aromuclear }\end{array}$ \\
\hline 670 & Cis- substituted alkenes (vinyl) \\
\hline 1724 & carboxylic ester \\
\hline
\end{tabular}

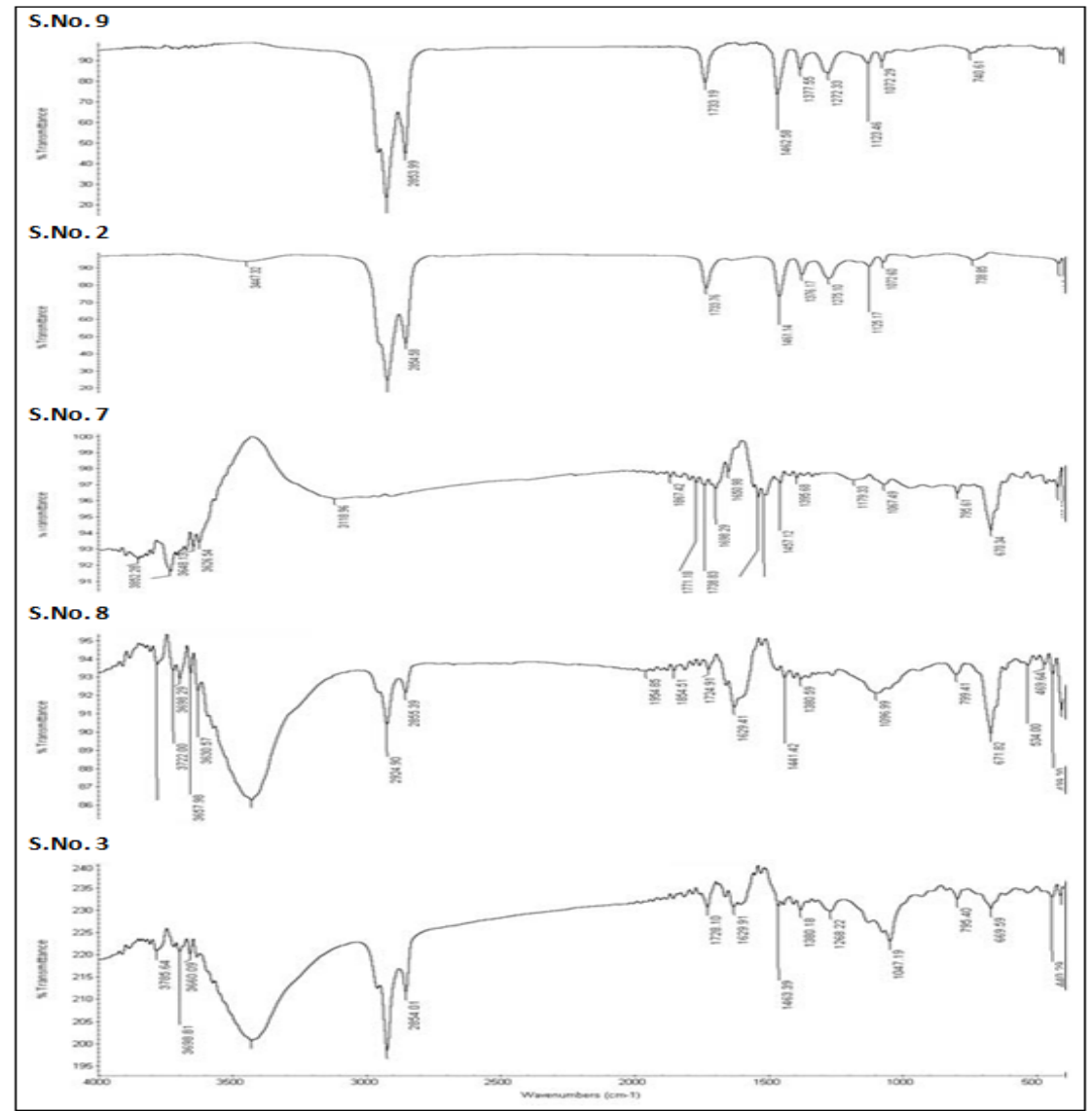

Fig.10. FT-IR absorption spectra for oils extracted from some selected water samples as an example of FT-IR analysis .

Egypt. J. Chem. 58, No. 1 (2015) 


\section{Conclusion and Recommendations}

This article provides important information on levels and sources of contamination by aliphatic and polycyclic aromatic hydrocarbons in surface waters sampled within the Suez Gulf. Quantitative analysis, made by gas chromatography, as well as its deducted geochemical parameters (UCM, $\mathrm{Pr} / \mathrm{Ph}$, $\mathrm{CPI}$ ) allows to conclude that hydrocarbon's origin could be linked to biogenic (plankton and terrestrial plants) and petrogenic inputs attesting of an oil contamination. The highest anthropogenic hydrocarbon inputs were found near the Refinery Company and Attaqa Electrical station with an unresolved complex mixture of aliphatic hydrocarbons, indicative of petrogenic inputs. PAHs contamination is closely related to petroleum spills, shipping, sewage input, and industrial activities. Molecular ratios indicated that PAHs in the surface waters were mostly petrogenic in origin likely due to shipping activities, whereas pyrogenic origin was found for PAHs in some sample probably due to the high combustion inputs and urban runoffs from urbanized areas. Comparison of the concentration range with a worldwide survey of surface waters PAH concentrations ranked PAH. PAH concentrations detected at the Inlet of (SOPC) site were sufficiently high to pose a risk to marine organisms if they are exposed continuously to this concentration. Hence, continuous monitoring of the ecosystem is highly warranted. The presences of aliphatic and aromatic hydrocarbons were confirmed by both FT-IR analysis and UV absorption spectra. Data on the aliphatic and polycyclic aromatic hydrocarbons found in this study can be used as baseline reference concentration for future monitoring programs.

\section{References}

1. Benlahcen, K.T., Chaoui, A., Budzinski, H., Bellocq, J. and Garrigues, P.H., Distribution and sources of polycyclic aromatic hydrocarbons in some Mediterranean coastal sediment. Mar. Pollut. Bull. 34, 298-305 (1997).

2. Benlahcen, K.T., Chaoui, A., Budzinski, H., Bellocq, J. and Garrigues, P.H., Distribution and sources of polycyclic aromatic hydrocarbons in some Mediterranean coastal sediment. Mar. Pollut. Bull. 34, 298-305 (1997).

3. Qiao, M., Wang, C., Huang, S., Wang, D. and Wang, Z., Composition, sources, and potential toxicological significance of PAHs in the surface sediments of the Meiliang Bay, Taihu Lake, China. Environ. Int. 32(1), 28-33 (2006).

4. Gogou, A., Bouloubassi, I. and Stephanou, E.G., Marine organic geochemistry of the Eastern Mediterranean: 1. Aliphatic and polyaromatic hydrocarbons in Cretan Sea sacrificial sediments. Mar. Chem. 68, 265-282 (2000).

5. Cripps, G.C., Problems in the identification of anthropogenic hydrocarbons against natural background levels in the Antarctic. Antarctic Sci. 14, 307-312 (1989). 
6. Humphrey, B., Boehm, P.D., Hamilton, M.C. and Norstrom, R.J., The fate of chemically dispersed and untreated crude oil in Arctic benthic biota. Arctic, 40, 149161 (1987).

7. Bouloubassi, I. and Saliot, A., Investigation of anthropogenic and natural organic inputs in estuarine sediments using hydrocarbon markers (NAH, LAB, PAH). Oenological Acta, 16(2), 145-161 (1993).

8. Mazurek, M. A. and Simoneit, B. R. T., Characterization of biogenic and petroleumderived organic matter in aerosols over remote, rural and urban areas In: L. H. Keith, (Ed.), Identification and Analysis of Organic Pollutants in Air, Ann Arbor Sciencel Butterworth, Boston, 353-370 (1984).

9. European Environment Agency, Europe's environment: D. Stanners, P. Bourdeau, the Dobris Assessment, Copenhagen, 712 pp. (1995).

10. Clark, R.B., Fourth, ed., Clarendon, P., Oxford, D.E. and Kucuksezgin, F., Distribution and origin of hydrocarbons in sacrificial sediments from the eastern Aegean Sea (Izmir Bay). Mar. Pollut. Bull. 54, 1813-1838 (1997).

11. Wei, M.C. and Jen, J.F., Determination of polycyclic aromatic hydrocarbons in aqueous samples by microwave assisted headspace solid-phase micro extraction and gas chromatography/flame ionization detection. Atlanta, 72(4), 1269-1274 (2007).

12. Katsoyiannis, A., Sweet, man, A.J. and Jones, K.C., PAH molecular diagnostic ratios applied to atmospheric sources: a critical evaluation using two decades of source inventory and air concentration data from the UK. Environmental Science and Technology, 45(20), 8897-8906 (2011).

13. Martinez, E., Gros, M., Lacorte, S. and Barcel'o, D., Simplified procedures for the analysis of polycyclic aromatic hydrocarbons in water, sediments and mussels. Journal of Chromatography A, 1047(2), 181-188 (2004).

14. Neff, J. M., Polycyclic Aromatic Hydrocarbons in the Aquatic Environment: Sources, Fates, and Biological Effects, Applied Science Publishers (1979).

15. Tam, N. F. Y., Wang, L. Ke, X.H. and Wong, Y. S., Contamination of polycyclic aromatic hydrocarbons in surface sediments of mangrove swamps. Environmental Pollution, 114(2), 255-263 (2001).

16. Szewczynska, M., Posniak, M. and Dobrzynska, E., Study on individual PAHs content in ultrafine particles from solid fractions of diesel and biodiesel exhaust fumes, Journal of Chemistry, 2013, Article ID 528471, 10 pages (2013).

17. Ashraf, M.W., Taqvi S.I.H., Solangi, A.R. and Qureshi, U.A., Distribution and risk assessment of polycyclic aromatic hydrocarbons in vegetables grown in Pakistan, Journal of Chemistry, 2013, Article ID 873959, 5 pages (2013).

18. REMIP WORKING GROUPS 2(WG2), JICA and EEAA, State oil pollution and Management in Suez Gulf region, page 15 (2008). 
19. Nazik, A. F., Mohamed, I., Omayma, E. A., Rabie, S. and Mostafa, M. E., State of Petroleum Pollution in the Suez Gulf Coastal Waters, The $17^{\text {th }}$ International Conference on Petroleum Mineral Resources and Development, Feb., 9 - 11 (2014).

20. Omayma, E. A., Nabila, A. A., Sawsan, A. M. and Mamdouh, M. D., Environmental Assessment of Contamination by Petroleum Hydrocarbons in the Aquatic Species of Suez Gulf, ISSN: 2166-074 Florida, USA. International Journal of Modern Organic Chemistry, 3, 1, 1-17 (2014).

21. Shou, F., Richard, A., Mowery, V.A., Castleberry Peter Van Walsum, G. and Kevin Chambills, High - performance liquid chromatography method for simultaneous determination of aliphatic products in biomass pretreatment hydrocarbons. Journal of Chromatography a, 1104, 54-61 (2006).

22. Ehrhardt, M. and Petrick, G., Relative concentrations of dissolved/dispersed fossil fuel residues in Mediterranean surface waters as measured by UV fluorescence. Marine Pollution Bulletin, 20, 560 -565 (1989).

23. Abd El Rahman, Mousa, Nazik, A. Farid, Maged, M. Soliman and Omyma, E. Ahmed, State of petroleum pollution in the south eastern Mediterranean Sea, Port Said coastal waters. Egypt. J. Petrol. 10(1), (2001).

24. Ehrhardt, M.G. and Burns, K.A., Hydrocarbons and related photo- oxidation products in Saudi Arabian Gulf coastal waters and hydrocarbons in underlying sediments and bio-indicator bivalves. Marine Pollution Bulletin, 27, 187-197 (1993).

25. Suriyan, S. and Gullaya W., Petroleum Hydrocarbon Contamination in Seawater along the Western Coast of the Philippines, Department of Marine Science, Chulalongkorn University, Bangkok 10330, Thailand, Southeast Asian Fisheries Development Center (1998).

26. Sultans, A. and Turkis, A., Petroleum Hydrocarbons in Saudi Red Sea Coastal Waters .JKAU: Mar. Sci. 8, 83-89 (1997).

27. Mohamed, Abd-EL-Hakem, S. and Abd-ELElla, MSC, Thesis entitled, Studies on oil pollutants in some selected important Egyptian marine environment (2004).

28. Shereet, S.M., Pollution of petroleum hydrocarbon in the new Damietta harbor, Egypt, Emirates Journal for Engineering Research, 14(1), 65-71, (2009).

29. Wahby, S.D. and El Deeb, K.Z., A, study of the state of pollution by petroleum hydrocarbons along the Alexandria Coast, Ves Journees Ehud Pollutions, Cagliari C.I.E.S.M., 257-262 (1980).

30. Awad, H., Hydrocarbon content in Red Sea surface waters and fishes in the region between Jeddah and Yanbu, Saudi Arabia. In: Proceedings of the First Conference on Environmental Sciences, Sabha, Lybia, In Arabic, English abstract, 27-31 January (1990).

31. El Samra, M.I., Emara, H.I. and Shunbo, F., Dissolved petroleum hydrocarbon in the northwestern Arabian Gulf, Marine Pollution Bulletin, 17(2), 65-68 (1986). 
32. Eman M. K., Thesis submitted for MSC, Physico-Chemical Studies on Some Selected Water Pollutants, Al-Azhar University, (2013).

33. MEPA, Environmental Protection Standard Document, Meteorology and Environment protection Administration, Saudi Arabia, No. 1409 - 01, P17, (1982).

34. Keizer, P.D. and Gordon, D.C. Jr., Detection of trace amounts of oil in sea water by Fluorescence spectroscopy. J. Fish. Res. Bd, Can 30, 1039-1045 (1973).

35. Saida, B., Soumaya, K., Ioanna, B., Alain, S. and Hassan, Er R., Assessment of the Moroccan Mediterranean Coasts contamination by hydrocarbons (non aromatic hydrocarbons, aromatic hydrocarbons and linear alkyl benzenes). International Journal of Geosciences, 2, 562-572 (2011).

36. Aceves, M, Grinalt, O., Albuiges, J., Broto, F., Comllas, L. and Gassrot, M., $J$. Chromatography, v 436, 503-509 (1998).

37. Dréau, Y., LeJacquot, F., Doumenenq, P., Guiliano, M., Bertrand, J. C. and Mille, G., Hydrocarbon balance of a site which had been highly and chronically contaminated by petroleum wastes of a refinery (from 1956 to 1992), Marine Pollution Bulletin, 34(6), 456-468 (1997).

38. Medeiros, P.M. and Bicego, M.C., Investigation of natural and anthropogenic hydrocarbon inputs In sediments using geo chemical Markers I. Santos, Sp. Brazil. Marine Pollution Bulletin, 49, 461 - 769 (2004).

39. Blumer, M., Guillard, R.R.L. and Chase, T., Hydrocarbons of Marine Phytoplankton. Marine Biology, 8(3), 183-189 (1971).

40. Burns, K.A., Greenwood, P., Benner, R., Brinkman, D., Brunskill, G., Codi, S. and Zagorskis, I., Organic biomarkers for tracing carbon cycling in the Gulf of Papua (Papua New Guinea). Continental Shelf Research, 24(19), 2373-2394 (2004).

41. Munoz, D., Guiliano, M., Doumenq, P., Jacquot, F., Scherrer, P. and Mille, C., Mar. Pollut. Bull. 34, 868 (1997).

42. Gough, M. A. and Rowland, M. A., Characterization of unresolved complex mixture of hydrocarbons in petroleum. Nature, 344(12), 648-650 (1990).

43. Bouloubassi, I., Fillaux, J. and Saliot, A., Hydrocarbons in surface sediment from the changing (Yangtze River) Estuary, East China Sea. Marine Pollution Bulletin, 42(12), 1335-1346 (2001).

44. Peña, E., Astroga-España, Ma. S. and Montelongo, G., Chemical fingerprinting applied to the evaluation of marine oil pollution in the coasts of the Canary Islands (Spain). Environmental Pollution, 111(2), 117-187 (2001).

45. Catherine, G., Marc, T., Sébastien, G. and Madeleine, G., Occurrence and distribution of hydrocarbons in the surface micro layer and subsurface water from the urban coastal marine area off Marseilles, Northwestern Mediterranean Sea. Marine Pollution Bulletin, 62, 2741-2752 (2011).

Egypt. J. Chem. 58, No. 1 (2015) 
46. Steinhauer, M. S. and Boehm, P. D., The composition and distribution of saturated and aromatic hydrocarbons in near shore sediments, river sediments and coastal peat of Alaskan Beaufort Sea: Implication for detecting anthropogenic hydrocarbon inputs. Marine Environmental Research, 33(4), 223- 253 (1992).

47. Atlas, R. M., Boehm, P. D. and Calder, J. A., Chemical and biological weathering of oil from the Amoco Cadiz Oil Spillage, within the Littoral Zone. Estuarine Coastal and Marine Science, 12, 589-608 (1981).

48. Gokdeniz, Nes,_er, Aynur, K., Deniz, U., Oya, A., Enis, D. , Esin, U. , Filiz, K. B., N. T.ul and Funda, Y., Polycyclic aromatic and aliphatic hydrocarbons pollution at the coast of Aliag a (Turkey) ship recycling zone. Marine Pollution Bulletin, 64, 1055-1059 (2012).

49. Gearing, P., Gearing, J., Lytle, T.F. and Lytle, J., Hydrocarbons in 60 northeast Gulf of Mexico shelf sediments: a preliminary survey. Geochim, Cosmo him. Ac. 40, 1005-1017 (1976).

50. Zhou, J. L. and Maskaoui, K., Distribution of polycyclic aromatic hydrocarbons in water and surface sediments from Daya Bay, China. Environmental Pollution, 121(2), 269-281 (2003).

51. Gonz'alez, J.J., Vĩnas, L. and Franco, M. A., Spatial and temporal distribution of dissolved/dispersed aromatic hydrocarbons in seawater in the area affected by the Prestige oil spill. Marine Pollution Bulletin, 53(5-7), 250-259 (2006).

52. Dhananjayan, V., Muralidharan, S. and Vinny and Peter, R. Occurrence and distribution of polycyclic aromatic hydrocarbons in water and sediment collected along the Harbor Line, Mumbai, India Hindawi Publishing Corporation . International Journal of Oceanography Volume Article ID 403615, 7 pages (2012).

53. Law, R. J., Dawes, V. J., Woodhead, R. J. and Matthiessen, P., Polycyclic aromatic hydrocarbons (PAH) in seawater around England and Wales. Marine Pollution Bulletin, 34(5), 306-322 (1997).

54. JØRGensen, S.E., Nielsen, S.N. and Jørgensen, L.A., Handbook of Ecological Parameters and Eco-toxicology, Elsevier, Amsterdam, the Netherlands (1991).

55. Nazik, A.F., Omayma E.A. and Abd EL-Rahman, M.M., Contamination of water, sediment, tar ball and fishes by poly-aromatic hydrocarbons (PAHs) in Alexandria Sea Coasts. Journal of Applied Sciences Research, ISSN 1819-544X., 9(11), 5619-5632 (2013).

56. Mohamed, I.A., Thesis submitted for MSc, Studied on water quality in selected area of Egypt, AL-Azhar University (2012).

57. Mostafa, M. E., Nazik, A. F., Enas, A. E., Omayma, E. A. and Eman, M. K., Origin and distribution of polycyclic aromatic hydrocarbons (PAHs) in surface water of Suez Gulf. Egypt. J. Anal. Chem. 23, 54-73 (2014). 
58. EPA, Environmental Protection Agency United States, National Recommended Water Quality Criteria (2009).

59. Werres, F., Balsaa, P. and Schmidt, T. C., Total concentration analysis of polycyclic aromatic hydrocarbons in aqueous samples with high suspended particulate matter content. Journal of Chromatography A, 1216(12), 2235-2240 (2009).

60. Tronczy'nski, J., Munschy, C., H'eas and Moisan, K., Contamination of the Bay of Biscay by polycyclic aromatic hydrocarbons (PAHs) following the T/V, Erika oil spill. Aquatic Living Resources, 17(3), 243-259 (2004).

61. Omar, N. Y. M. J., Abas, M. R. B., Rahman, N. A., Tahir, N. M., Rushdi, A. I. and Simoneit, B. R. T., Levels and distributions of organic source tracers in air and roadside dust particles of Kuala Lumpur, Malaysia. Environmental Geology, 52(8), 1485-1500 (2007).

62. Mosisch, T.D. and Arthington, A.H., Polycyclic aromatic hydrocarbon residues in the sediments of a dune lake as a result of power boating. Lakes and Reservoirs, 6(1), 21-32 (2001).

63. Soclo, H. H., Garrigues, P. and Ewald, M., Origin of polycyclic aromatic hydrocarbons (PAHs) in coastal marine sediments: case studies in Continuo (Benin) and Aquitaine (France) Areas. Marine Pollution Bulletin, 40(5), 387-396 (2000).

64. Essam, N., Lee, Y. H., Zuriati, Z. and Salmijah, S., Concentrations and sources of polycyclic aromatic hydrocarbons in the seawater around Langkawi Island, Malaysia, Hindawi Publishing Corporation. Journal of Chemistry, 2013, 10 pages (2013).

65. Boonyatumanond, R., Murakami, M., Wattayakorn, G., Togo A. and Takada, H., Sources of polycyclic aromatic hydrocarbons (PAHs) in street dust in a tropical Asian mega-city, Bangkok, Thailand. Science of the Total Environment, 384(1-3), 420-432 (2007).

66. Neveka, A., Bionda, K., S. and Rak, N., International Journal of Environmental Analytical Chemistry, 39,381 (1990).

67. Zhengzhen, Z., Zhanfei, L. and Laodong, G., Chemical evolution of Macon does crude oil during laboratory degradation as characterized by fluorescence EEMs and hydrocarbon composition. Marine Pollution Bulletin, 66, 164-175 (2013).

68. Keroly, A.P.,Colati, G. P., Dalmaschio, E. V.R. de, Castro, A. O., Gomesb, B. G. and Vaz, W.R., Monitoring the liquid/liquid extraction of naphthenic acids in Brazilian crude oil using electro spray ionization FT-ICR mass spectrometry (ESI FT-ICR MS). Fuel, 108, 647-655 (2013). 


\section{وجود وتوزيع المركبات الأليفاتية والهيدروكريونات العطرية فى المئي

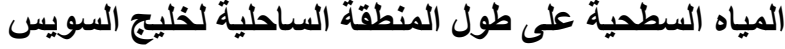

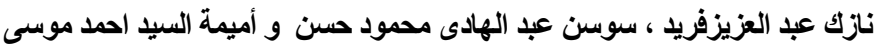

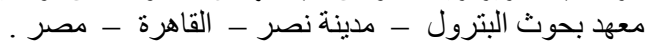

تهدف هذه الدراسه إلى رصد التلوث بنفايات السفن التي تلقى في مياه و شو اطئ

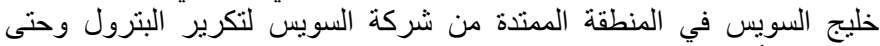

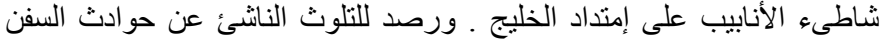

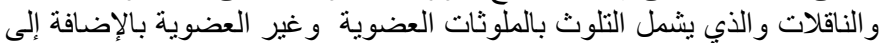

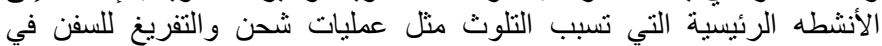

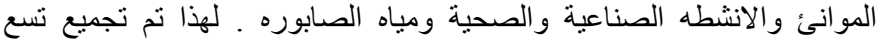

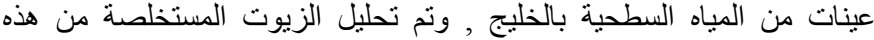

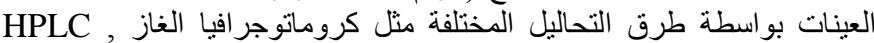

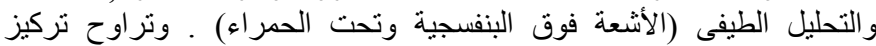

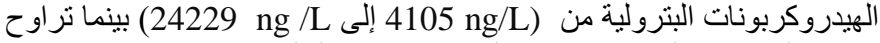

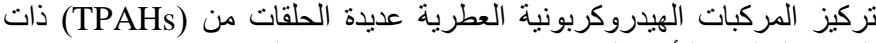

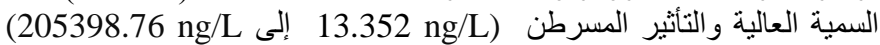

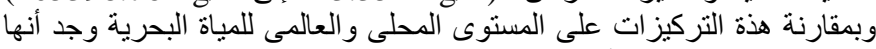

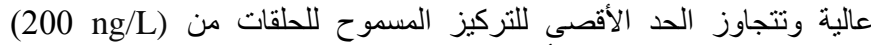

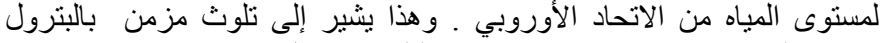

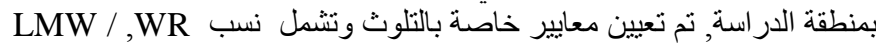
ومعامل الأفضلية

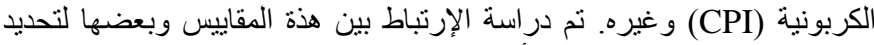

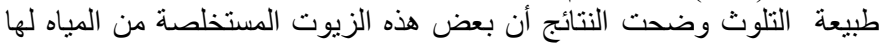

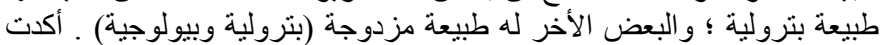

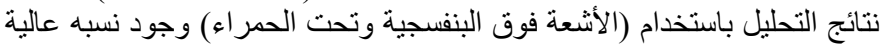

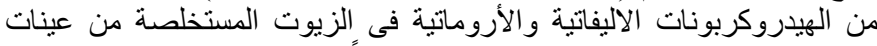

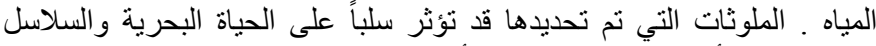

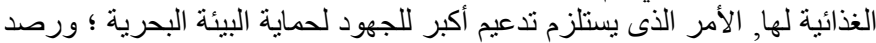

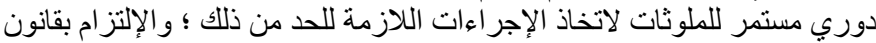

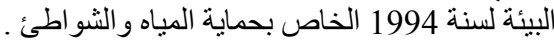

